\title{
The role of highly oxygenated molecules (HOMs) in determining the composition of ambient ions in the boreal forest
}

\author{
Federico Bianchi ${ }^{1, *}$, Olga Garmash ${ }^{1}$, Xucheng $\mathrm{He}^{1}$, Chao Yan $^{1}$, Siddharth Iyer ${ }^{2}$, Ida Rosendahl ${ }^{3}$, Zhengning Xu ${ }^{4}$, \\ Matti P. Rissanen ${ }^{1}$, Matthieu Riva ${ }^{1}$, Risto Taipale ${ }^{1}$, Nina Sarnela ${ }^{1}$, Tuukka Petäjä ${ }^{1}$, Douglas R. Worsnop ${ }^{1,5}$, \\ Markku Kulmala ${ }^{1}$, Mikael Ehn ${ }^{1}$, and Heikki Junninen ${ }^{1,6}$ \\ ${ }^{1}$ Department of Physics, University of Helsinki, 00014 Helsinki, Finland \\ ${ }^{2}$ Department of Chemistry, University of Helsinki, 00014 Helsinki, Finland \\ ${ }^{3}$ Arctic Research Centre, Aarhus University, 8000 Aarhus, Denmark \\ ${ }^{4}$ Joint International Research Laboratory of Atmospheric and Earth System Sciences, School of Atmospheric Sciences, \\ Nanjing University, 210023 Nanjing, China \\ ${ }^{5}$ Aerodyne Research, Inc., Billerica, MA 01821, USA \\ ${ }^{6}$ Institute of Physics, University of Tartu, 50090 Tartu, Estonia \\ * Invited contribution by Federico Bianchi, recipient of the EGU Arne Richter Award for \\ Outstanding Early Career Scientists 2017.
}

Correspondence to: Federico Bianchi (federico.bianchi@helsinki.fi)

Received: 19 May 2017 - Discussion started: 31 May 2017

Revised: 17 August 2017 - Accepted: 20 September 2017 - Published: 20 November 2017

\begin{abstract}
In order to investigate the negative ions in the boreal forest we have performed measurements to chemically characterise the composition of negatively charged clusters containing highly oxygenated molecules (HOMs). Additionally, we compared this information with the chemical composition of the neutral gas-phase molecules detected in the ambient atmosphere during the same period. The chemical composition of the ions was retrieved using an atmospheric pressure interface time-of-flight mass spectrometer (APiTOF-MS) while the gas-phase neutral molecules (mainly sulfuric acid and HOMs) were characterised using the same mass spectrometer coupled to a nitrate-based chemical ionisation unit (CI-APi-TOF). Overall, we divided the identified HOMs in two classes: HOMs containing only carbon, hydrogen and oxygen and nitrogen-containing HOMs or organonitrates (ONs). During the day, among the ions, in addition to the well-known pure sulfuric acid clusters, we found a large number of HOMs clustered with nitrate $\left(\mathrm{NO}_{3}^{-}\right)$or bisulfate $\left(\mathrm{HSO}_{4}^{-}\right)$, with the first one being more abundant. During the night, the distribution of ions, mainly composed of HOM clustered with $\mathrm{NO}_{3}^{-}$, was very similar to the neutral compounds that are detected in the CI-APi-TOF as adducts with the artificially introduced primary ion $\left(\mathrm{NO}_{3}^{-}\right)$.

For the first time, we identified several clusters containing up to 40 carbon atoms. These ions are formed by up to four
\end{abstract}

oxidised $\alpha$-pinene units clustered with $\mathrm{NO}_{3}^{-}$. While we know that dimers (16-20 carbon atoms) are probably formed by a covalent bond between two $\alpha$-pinene oxidised units, it is still unclear what bonding formed larger clusters.

Finally, diurnal profiles of the negative ions were consistent with the neutral compounds revealing that ONs peak during the day while HOMs are more abundant at night-time. However, during the day, a large fraction of the negative charge is taken up by the pure sulfuric acid clusters causing differences between ambient ions and neutral compounds (i.e. less available charge for $\mathrm{HOM}$ and $\mathrm{ON}$ ).

\section{Introduction}

Ions are present everywhere in the atmosphere. They arise from, for example, galactic cosmic rays (GCR) and/or radioactive decay from the soil (radon and gamma; Harrison and Carslaw, 2003; Hirsikko et al., 2011). The initial ions have generally a very simple structure. In the upper atmosphere, the primary ions are $\mathrm{O}^{+}, \mathrm{O}_{2}^{+}$and $\mathrm{NO}^{+}$, while in the dense air they are $\mathrm{N}_{2}^{+}, \mathrm{O}_{2}^{+}, \mathrm{O}_{2}^{-}$and $\mathrm{O}^{-}$(Smith and Spanel, 1995). Collisions of these ions with various trace gases lead to charge transfer to compounds with higher charge affinity and formation of a large variety of cluster ions. Neg- 
ative charge is preferably transferred to acidic compounds like nitric acid, sulfuric acid and few other strong acids (lowest proton affinity), while positive charge is carried by basic compounds such as ammonia and amines (highest proton affinity; Smith and Spanel, 1995). The production rate of the ions can vary depending on the altitude, location and the time of the year. In the boreal forest, such as Hyytiälä, located at $61^{\circ} \mathrm{N}$, early spring average production rate calculated based on external radiation and radon measurements is about 4.5 ion pairs $\mathrm{cm}^{-3} \mathrm{~s}^{-1}$ (Laakso et al., 2004).

It is well known that ambient ions are able to enhance the formation rate of new particles and the mechanism is known as ion-induced nucleation (Raes et al., 1986; Yu and Turco, 2001; Kirkby, 2007; Arnold, 2008; Hirsikko et al., 2011). Recent laboratory experiments performed in the European Centre for Nuclear Research (CERN; CLOUD experiment) have systematically explored the influence of ions on new particle formation (NPF) in several different chemical systems. The presence of ions strongly enhanced pure sulfuric acid nucleation (Kirkby et al., 2011; Duplissy et al., 2016) as well as sulfuric acid-ammonia nucleation (Kirkby et al., 2011; Bianchi et al., 2012; Schobesberger et al., 2015; Kürten et al., 2016), while showing little to no effect on sulfuric acid-amine nucleation (Almeida et al., 2013; Kürten et al., 2014; Bianchi et al., 2014). Recently, the results from the same experiment revealed that ions can also strongly enhance pure organic nucleation in absence of sulfuric acid (Kirkby et al., 2016). Although Bianchi et al. (2016) observed that new particle formation in the free troposphere depends on the availability of highly oxidised organic species, they saw only a weak ion enhancement. Several studies have also demonstrated that the compounds participating in this process, highly oxygenated molecules (HOMs), often play a central role in NPF events (Kulmala et al., 1998; Ehn et al., 2014; Krechmer et al., 2015; Ortega et al., 2016; Kirkby et al., 2016; Bianchi et al., 2016).

HOMs can exist in the atmosphere both as part of an ion (ligand with a core ion) or neutral species in the gas phase (Ehn et al., 2012, 2014; Bianchi et al., 2016). Main source of HOM to the atmosphere is likely the oxidation of terpenes, which are biogenically emitted volatile organic compounds (BVOCs). The most abundant HOM precursor in the boreal forest is $\alpha$-pinene, originating primarily from coniferous trees (Ehn et al., 2014; Jokinen et al., 2015). Ehn et al. (2014) highlighted the formation of HOMs as first-generation oxidation products from the oxidation of monoterpenes. The HOMs are produced through the formation of peroxy radicals $\left(\mathrm{RO}_{2}\right)$ and subsequent intramolecular hydrogen-shifts followed by rapid reactions with oxygen, also called "autoxidation" (Crounse et al., 2013; Rissanen et al., 2014; Jokinen et al., 2015; Berndt et al., 2016). They are expected to contain a wide range of chemical functional groups, including hydroxyl, hydroperoxides, carbonyls and epoxides. Consequently, some of the HOMs have very low vapour pressures allowing them to react and/or condense nearly irreversibly onto aerosol surfaces (Tröstl et al., 2016).

In oxidation of monoterpenes, such as $\alpha$-pinene, characteristic HOMs contain similar amount of carbon and hydrogen to the parent molecule (i.e. $\mathrm{C}_{10} \mathrm{H}_{16}$ ), while the oxygen amount varies and can be as high as 13 atoms (Ehn et al., 2012, 2014; Tröstl et al., 2016; Kirkby et al., 2016). Beside monomer HOMs $\left(\mathrm{C}_{10}\right)$, dimer HOMs with an approximate composition of either $\mathrm{C}_{19} \mathrm{H}_{28} \mathrm{O}_{x}$ or $\mathrm{C}_{20} \mathrm{H}_{30} \mathrm{O}_{x}$ were also observed in both gas and particulate phases (Ehn et al., 2014; Lopez-Hilfiker et al., 2014). Rissanen et al. (2014) and Ehn et al. (2014) proposed that the bimolecular reactions of two peroxy radicals $\left(\mathrm{RO}_{2}+\mathrm{RO}_{2}\right)$ are one of the likely chemical pathways leading to the formation of dimers in the gas phase.

Organonitrates (ONs) were also identified in both gas and particulate phases from the oxidation of biogenic compounds in the presence of $\mathrm{NO}_{x}\left(\mathrm{NO}+\mathrm{NO}_{2}\right)$ and $\mathrm{NO}_{3}$ radicals (Ehn et al., 2014; Lee et al., 2016; Yan et al., 2016). In addition to carbon, hydrogen and oxygen, these molecules contain at least one nitrogen atom. Different reaction pathways leading to $\mathrm{ON}$ formation have been proposed. Due to their low vapour pressures, ONs are also expected to have a potentially important role in the formation and growth of secondary organic aerosol (SOA; Farmer et al., 2010; Kiendler-Scharr et al., 2016; Lee et al., 2016; Ng et al., 2017). In addition, Kulmala et al. (2013) recently proposed that the organonitrate $\mathrm{C}_{10} \mathrm{H}_{15} \mathrm{O}_{5} \mathrm{NO}_{3}$ is important player in NPF and Jokinen et al. (2017) confirmed that the abundance of ONs during solar eclipse correlates with clustering.

Although recently it has been demonstrated that the ions as well as the HOMs are very important during NPF processes, their role in the boreal forest is still somewhat unclear. It has been shown that ion nucleation can contribute up to $10 \%$ of the total nucleation; however, it is still not known what the role of the different ion families is (Kulmala et al., 2013). While few previous studies have shown the presence of HOMs in the ambient ions, a careful comparison between those clusters and neutral organic compounds has not been attempted so far. The aim of this study was to investigate the composition and diurnal changes of ambient negative ions, focusing on the ions composed of HOMs, ONs and sulfuric acid comparing them with the neutral species.

\section{Materials and methods}

All measurements presented in this study were performed at the Station for Measuring Ecosystem-Atmosphere Relations (SMEARII) located at Hyytiälä Forestry Field Station in southern Finland (Hari and Kulmala, 2005) during spring 2013, covering April, May and June. The SMEARII station is located on flat terrain covered by a homogeneous Scots pine (Pinus sylvestris) forest which is representative of the boreal coniferous forest. Two atmospheric pressure interface timeof-flight mass spectrometers (APi-TOF-MSs; Aerodyne Re- 
search Inc. \& Tofwerk AG; Junninen et al., 2010) in Hyytiälä were deployed to obtain data on ambient negative ions and neutral molecules. An APi-TOF consists of a time-of-flight mass spectrometer (TOF-MS) coupled to an atmospheric pressure interface unit (APi) that allows sampling directly from the ambient air. The instrument that is used for detection of neutral molecules is further equipped with a chemical ionisation (CI) inlet (Jokinen et al., 2012).

In the APi-TOF, the ions are sampled directly from the air (Junninen et al., 2010), while in the CI-APi-TOF, the ions are artificially created in the chemical ionisation inlet that is placed in front of the APi-TOF. The CI-APi-TOF inlet utilised nitrate-ionisation method and was designed initially to measure neutral sulfuric acid, and later on was shown to also detect HOMs and ONs (Jokinen et al., 2012; Ehn et al., 2014). Chemical ionisation is achieved by exposing clean air (sheath flow) containing nitric acid $\left(\mathrm{HNO}_{3}\right)$ to alpha radiation $\left(10 \mathrm{MBq}^{241} \mathrm{Am}\right.$ source) or X-rays, which produces nitrate $\left(\mathrm{NO}_{3}^{-}\right)$ions. $\mathrm{NO}_{3}^{-}$ions in the sheath flow are directed into the sample flow by an electric field where by forming an adduct (e.g. with HOM) or by proton transfer reaction (e.g. with sulfuric and some dicarboxylic acids) neutral ambient molecules are charged and detected. The ionised molecules/adducts are then guided through a critical orifice to the TOF mass analyser. Sulfuric acid quantification was achieved with a calibration unit that was based on the setup described by Kürten et al. (2011). No direct calibration regarding the HOMs was performed; therefore, the methodology described by Ehn et al. (2014), using the calibration constant of sulfuric acid, was adopted to derive their concentrations.

$\mathrm{NO}_{3}^{-}$clustering ionisation is very selective to highly functionalised organic compounds (the molecule should have at least two hydroxy or hydroperoxy groups), which makes this method ideal for measurement of HOMs (Hyttinen et al., 2015). High resolving power of TOF mass analyser makes it possible to identify the chemical composition of the detected molecules. The mass spectrometry data were processed and analysed using the MATLAB-implemented latest version (6.03) of tofTools developed by Junninen et al. (2010).

For the purposes of this study, we will refer to nonnitrogen containing organics as "HOM monomers" $\left(\mathrm{C}_{10}\right.$ molecules) and "HOM dimers" ( $\mathrm{C}_{20}$ molecules). We will use "ONs" to refer to the nitrogen-containing HOMs. When discussing ions, we will refer as "HOM/ON-nitrate" and "HOM/ON-bisulfate" to clusters of $\mathrm{HOMs} / \mathrm{ONs}$ with $\mathrm{NO}_{3}^{-}$ and $\mathrm{HSO}_{4}^{-}$ions respectively.

\section{Results and discussion}

The focus of this work is to investigate the chemical composition of the ambient ions that contain HOM in the boreal forest and compare it with the neutral compounds detected by the CI-APi-TOF. Ehn et al. (2010) have previously reported that during the day the main peaks observed are cluster composed of sulfuric acid, whereas during night the identified ions are mainly formed by HOMs clustered with $\mathrm{NO}_{3}^{-}$. However, no information was retrieved regarding the chemical composition of the ambient ions containing HOM and ON present during the day. Day and night ambient ions spectra, averaged throughout the campaign, were analysed and detailed chemical composition analyses are provided for a typical clear sky day (diurnal and nocturnal spectra). Finally, we compared the negative ions with the neutral compounds detected by the CI-APi-TOF.

Figure 1 presents the average mass spectra with a mass resolution of one atomic mass unit, focusing on the HOM region between $m / z 250$ and 650 (mass-to-charge ratio), the least studied so far, of 10 clear-sky days during April and May 2013 of the negative ions (Fig. 1a and c) and neutral molecules (Fig. 1b and d). The daily spectra (Fig. 1a and $b$ ) are an average of all of the mass spectra recorded from 09:00 to 13:00 LT (local time), while during the night (Fig. 1a and d) the mass spectra cover the time range from 23:00 until 03:00 LT. Peaks with an odd and even $\mathrm{m} / z$ are coloured in blue and red respectively as a first simple indication of the nitrogen-containing molecules. This is based on the nitrogen rule, where a deprotonated molecule/cluster containing one (odd) nitrogen will have an even mass $\left(\mathrm{HOM} \cdot \mathrm{NO}_{3}^{-}\right.$ and/or $\mathrm{ON} \cdot \mathrm{HSO}_{4}^{-}$). While a deprotonated molecule/cluster containing zero or two (even) nitrogen will have an odd mass $\left(\mathrm{ON} \cdot \mathrm{NO}_{3}^{-}\right.$and/or $\left.\mathrm{HOM} \cdot \mathrm{HSO}_{4}^{-}\right)$. The rule is reversed for radical species that can be detected by CI-APi-TOF. It is important to note that the raw signal (counts per second) of the ambient ions is about an order of magnitude lower than the one measured for the neutral compounds. This, after considering the instrument calibration, reflects a difference in concentrations of several orders of magnitude (Fig. 5a and b). Although present in low concentrations, ambient ions can have a direct impact on atmospheric processes, such as new particle formation (Kirkby et al., 2011, 2016).

As previously reported by Yan et al. (2016), during daytime, the mass spectra for the neutral compounds are dominated by the species with an odd mass number $\left(\mathrm{ON} \cdot \mathrm{NO}_{3}^{-}\right)$, while during the night-time peaks with an even mass number $\left(\mathrm{HOM} \cdot \mathrm{NO}_{3}^{-}\right)$are the most abundant. From Fig. 1, we can see a similar pattern for the ambient ions, although with some differences. While for the neutral compounds there is a clear odd/even pattern during the day, the negative ions show only a small predominance of the odd masses. The main reason is that while in the ionisation unit of the CI-APi-TOF the HOMs and the ONs form almost exclusively an adduct with the primary ion $\left(\mathrm{NO}_{3}^{-}\right)$, in the atmosphere, during the day, the HOMs and the ONs are forming clusters with $\mathrm{NO}_{3}^{-}$ or $\mathrm{HSO}_{4}^{-}$ions. As $\mathrm{ON}-$ nitrate will appear as odd mass and $\mathrm{ON}$-bisulfate will appear as even mass, the difference between odd and even $m / z$ is less pronounced. This was the first detection of this type of ion clusters during the daytime 


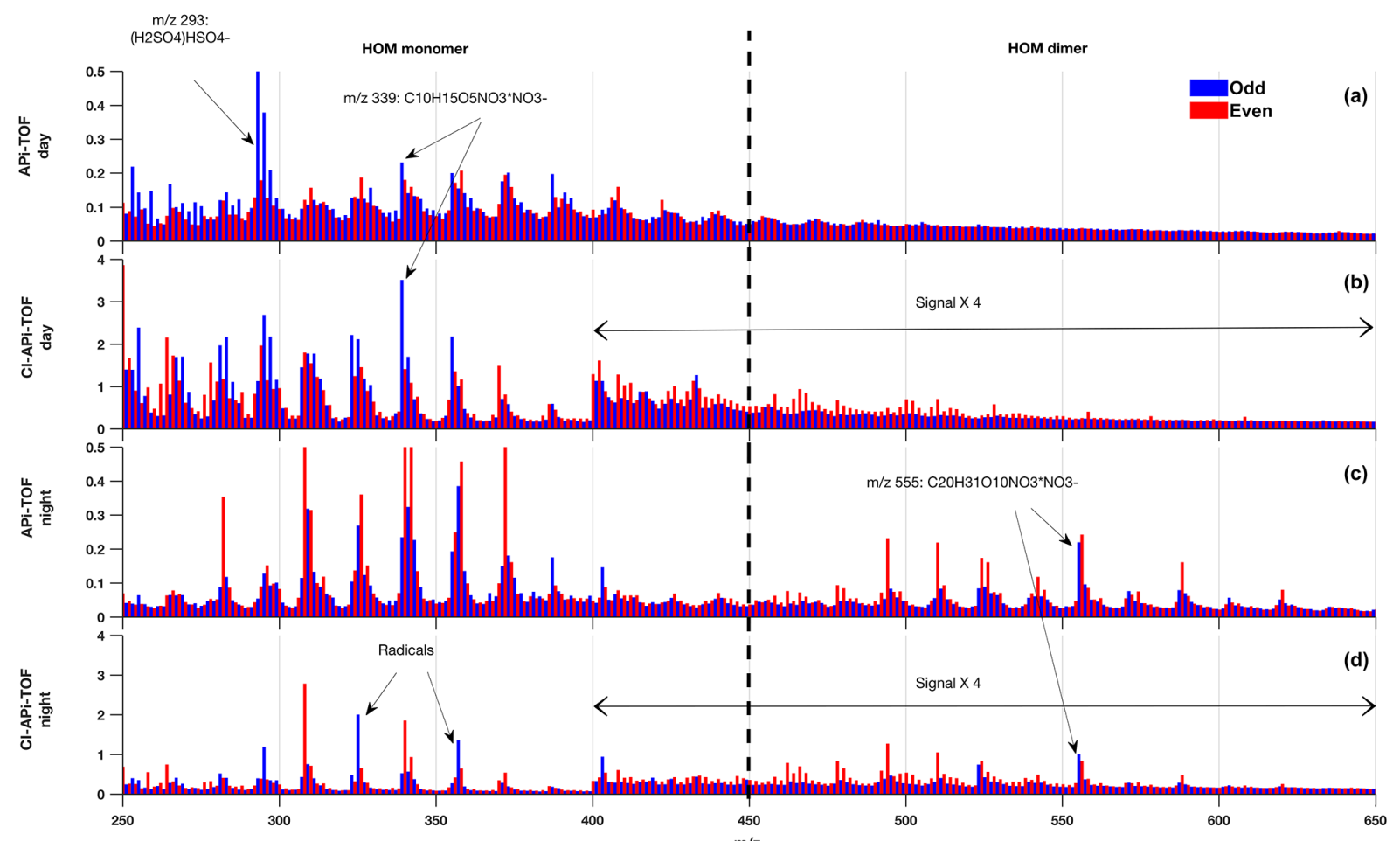

Figure 1. Averaged mass spectra of 10 days (clear sky conditions) of measurements during April and May 2013. The $y$ axes represent the peak intensity in counts per second. Note that the intensities of the measured ions (APi-TOF) are an order of magnitude lower than the one detected after being ionised in the CI unit. Panels (a, b) show respectively negative ions (APi-TOF) and neutral clusters (CI-APi-TOF) during the day (09:00-13:00 LT). Panels (c, d) show respectively negative and neutral clusters during the night (23:00-03:00 LT). Odd masses have been colour coded in blue and even masses in red. The two black arrows in (b) and (d) show the area of the spectrum where the signal has been multiplied by 4 (done only for the CI-APi-TOF).

in the ambient atmosphere, especially the adducts formed by the organonitrates.

During the night, these organic species are mainly forming a cluster with the $\mathrm{NO}_{3}^{-}$ions since the photochemical production of sulfuric acid, and therefore $\mathrm{HSO}_{4}^{-}$ions, is inhibited. As a result, the composition of ambient ions is very similar to the neutral molecules once they are ionised by the CI-APi-TOF making the final two spectra in Fig. 1c and d comparable. However, there are still some differences; in both mass spectra, in the monomer region, we can still observe few peaks at high intensity with an odd atomic number. These peaks are radicals formed from the ozonolysis of monoterpenes $\left(m / z 325-\mathrm{C}_{10} \mathrm{H}_{15} \mathrm{O}_{8} \cdot \mathrm{NO}_{3}^{-}\right.$and 357$\mathrm{C}_{10} \mathrm{H}_{15} \mathrm{O}_{10} \cdot \mathrm{NO}_{3}^{-}$; Ehn et al., 2014; Yan et al., 2016) and are highlighted in Fig. 1a. Contrary to a one large group of ions/neutral compounds within $m / z 250$ to 500 observed during the day, during night two groups of molecules were distinguished. The first group of peaks, from $m / z 250$ to 450 , is composed of HOMs clustered with $\mathrm{NO}_{3}^{-}$ions containing 810 carbon atoms (HOM monomer). The second group (from $m / z 450$ to 650) are also HOMs clustered with $\mathrm{NO}_{3}^{-}$ions but comprised of a larger number of carbon atoms $\left(\mathrm{C}_{16}-\mathrm{C}_{20}\right)$ and are assigned to HOM dimers. Several studies have now reported that such dimer compounds are formed from the ozonolysis of $\alpha$-pinene (Ehn et al., 2014; Tröstl et al., 2016; Kirkby et al., 2016). In addition, in this case, there are still some peaks at odd masses (i.e. $\mathrm{m} / z$ 555: $\mathrm{C}_{10} \mathrm{H}_{31} \mathrm{O}_{10} \mathrm{NO}_{3}$ ) that have been attributed to night-time $\mathrm{NO}_{3}$ chemistry (Yan et al., 2016).

\subsection{Detailed chemical composition}

To get further chemical information we investigated a specific day with high-resolution peak fitting. A revealing way to present and compare qualitatively mass spectra is the mass defect plot (Schobesberger et al., 2013; Bianchi et al., 2014). In those plots, the abscissa represents the measured $\mathrm{m} / \mathrm{z}$ of the compounds and the ordinate their mass defect, which is the difference between the exact mass and the nominal mass (e.g. the exact mass of oxygen ${ }^{16} \mathrm{O}$ is $15.9949 \mathrm{~m} / \mathrm{z}$ and its mass defect is thus $-0.0051 \mathrm{~m} / \mathrm{z}$ ). In these plots, the symbol size is proportional to the peak intensity. However, these peaks can have an intensity that differs by orders of magnitude so we use logarithmic scale to present the concentration. As a result, it is difficult to see the differences in quantities 

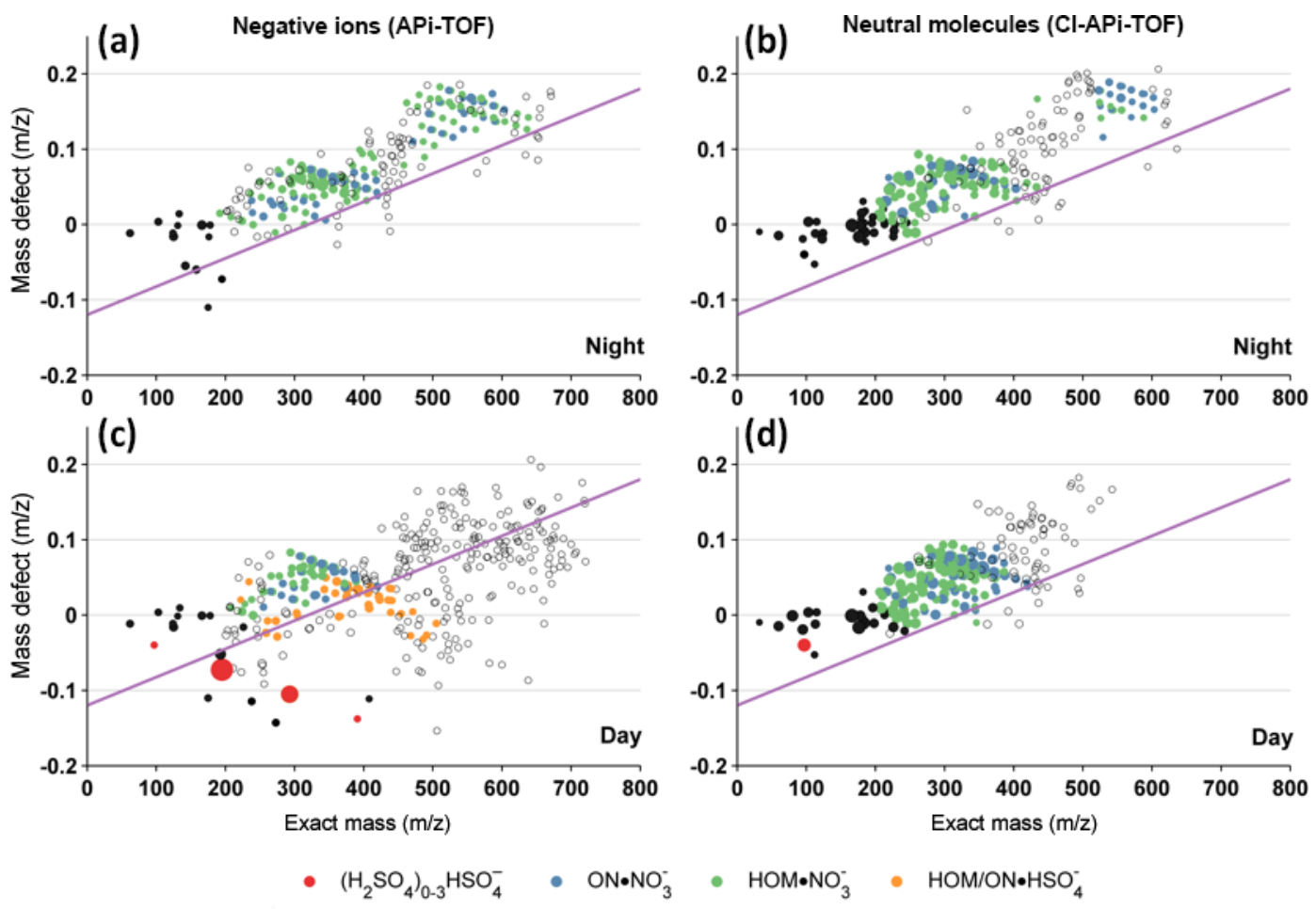

Figure 2. Mass defect plots for the neutral clusters and negative ions during 20 April 2013. Panels (a, b) show the night-time chemical composition of the negative and neutral clusters respectively. Panels (c, $\mathbf{d})$ show the chemical composition during the day of the negative and neutral clusters respectively. The size of the circle represents the area of the peaks and is proportional to the detected amount. All four plots show the clusters/ligands as seen by the detector, therefore including the ligand $\left(\mathrm{NO}_{3}^{-}\right)$in the case of the neutral molecules. The compounds are coloured according to their chemical composition. Open circles represent the unidentified compounds, while the black dots represent other identified peaks such as small organic acids. The violet line underlines the most oxidised HOMs detected by CI-APi-TOF as clusters with $\mathrm{NO}_{3}^{-}$ions. It is very likely that most of the unidentified negative ions that are placed below the line are $\mathrm{HOM}$ clusters with $\mathrm{HSO}_{4}^{-}$ions or $\mathrm{H}_{2} \mathrm{SO}_{4} \mathrm{HSO}_{4}^{-}$acid clusters.

looking at the size of the dots. Therefore, the differences in intensities is more clear in Fig. 5.

In Fig. 2, we show mass defect plots of the negative ambient ions and gas-phase molecules (in the plot the neutral molecules are attached to the ligand that in this case is $\mathrm{NO}_{3}^{-}$) during the night (23:00-03:00 LT; top panels) and during the day (09:00-13:00 LT; bottom panels) on 20 April 2013. In all four mass defect plots, the coloured filled dots correspond to the identified group of compounds described in the legend and the open circles represent the unidentified species.

As expected and partially shown in previous studies (Ehn et al., 2012; Yan et al., 2016), the chemical composition of the negative ions and the neutral compounds is different between day and night. In Fig. 1, the neutral molecules as well as the negative ions indicate that, during the day, ONs, formed by the reaction between monoterpene, ozone and NO, have higher concentration than during the night (light blue dots) while, the HOMs (mainly formed by $\alpha$-pinene ozonolysis) peak during night (green dots). Interestingly, larger concentration of organic compounds such as HOM dimers could also be observed during the night, which is consistent with a decrease in the NO concentration and subsequent increase in self and cross-reactions of $\mathrm{RO}_{2}$ radicals. From Fig. 2, we can clearly see that during the night ambient ions and neutral compounds (after being ionised in the ionisation unit) have similar composition. Several studies have discussed that most of the HOMs detected during the night are formed by the reaction of monoterpene (e.g. $\alpha$-pinene) with ozone (Schobesberger et al., 2013; Ehn et al., 2014; Tröstl et al., 2016; Kirkby et al., 2016). Some of these studies have also shown that via the same reaction (i.e. $\alpha$-pinene ozonolysis) it is possible to form clusters that contain several $\mathrm{C}_{10}$ monomers $\left(\mathrm{C}_{20}, \mathrm{C}_{30}\right.$ and $\left.\mathrm{C}_{40}\right)$. In addition, Yan et al. (2016) also observed the formation of the HOM dimers $\left(\mathrm{C}_{19}-\mathrm{C}_{20}\right)$ during the night. Besides these oligomers, other ONs (blue dots) were also observed during night. These ONs are quite different from the one observed during the day because they are formed by a different reaction, where the oxidation of monoterpene is initiated by the $\mathrm{NO}_{3}$ radical, highlighting once more the different $\mathrm{NO}_{x}$ chemistry during day and night. It is worth noting that such behaviour has been observed previously for the neutral molecules, where the ONs and HOMs 
are more abundant during the day and night-time respectively (Yan et al., 2016).

The ambient negative ions reveal a new group of compounds which are $\mathrm{HOMs}$ and $\mathrm{ONs}$ clustered with $\mathrm{HSO}_{4}^{-}$ ions. Since sulfuric acid (and consequently the bisulfate ion) is produced mainly during daytime from the $\mathrm{OH}$-initiated oxidation of $\mathrm{SO}_{2}$, the differences in composition of ambient ions and neutral species is larger during the day. For example, at noon, all major ambient ions are composed of $\mathrm{HSO}_{4}^{-}$ $\left(m / z\right.$ 97), sulfuric acid dimer $\left(\mathrm{H}_{2} \mathrm{SO}_{4} \mathrm{HSO}_{4}^{-} ; m / z\right.$ 195) and trimer $\left(\left(\mathrm{H}_{2} \mathrm{SO}_{4}\right)_{2} \mathrm{HSO}_{4}^{-} ; m / z 293\right)$, while the neutral sulfuric acid measured by the CI-APi-TOF is not the dominant peak (see also Fig. 5). This is due to the strong electron affinity of sulfuric acid. The other remarkable feature in the negative ion spectra is the daytime band of peaks (open circles in Fig. 2c) that spreads on the mass defect plot wider than nighttime dimers (Fig. 2a) and daytime neutral species (Fig. 2d). As shown in Fig. 2, these peaks are still unidentified. We suggest that some of the peaks reported in Fig. 2c are HOMs and ONs as seen in the neutral mass spectra, but clustered with $\mathrm{HSO}_{4}^{-}$ions. This is consistent with the fact that a lot of peaks have a near-zero or negative mass defect. To highlight the presence of these different species in the APi-TOF during the day, a reference line (violet) was added. This line represents the adducts with the clusters having the lowest mass defect, and therefore the most oxidised HOMs or ONs clustered with $\mathrm{NO}_{3}^{-}$(Fig. 2b). By definition, in the CI-APi-TOF, all peaks appeared above the line because of the chemical ionisation mechanism that is used in this instrument. During the nighttime, the ambient ions are also all above the line, because in this case the ions are mainly formed by HOMs or ONs cluster with $\mathrm{NO}_{3}^{-}$ions, which is the same mechanism inside the CIAPi-TOF. However, during daytime, the behaviour is totally different. The band is much broader and many new peaks are situated below this line, suggesting that HOMs and ONs are clustered with $\mathrm{HSO}_{4}^{-}$ions (orange dots). In addition, formation of ambient ions containing sulfuric dimer or trimer as a core ion might be expected and could explain the formation of some ions observed solely during the day, especially the ones with highly negative mass defect. It is worth noting that sulfuric acid-HOM clusters have been demonstrated to participate in NPF (Schobesberger et al., 2013; Riccobono et al., 2014) and similarly might be involved in such processes in the boreal forest. This is the first time that such clusters have been detected in the ambient atmosphere during the day.

In addition to the mass defect plots presented in Fig. 2, the chemical composition of the ambient ions measured during several nights the year before (for this specific case it was recorded on 13 March 2012) is presented in Fig. 3. It is important to mention that during that time the instrument was tuned to detect ambient ions at very high masses and could likely explain why such an observation was not possible during the 2013 campaign (Fig. 2). In addition to two bands of monomers and dimers observed in Fig. 2, Fig. 3 depicts the existence of larger molecules, likely trimer and tetramer

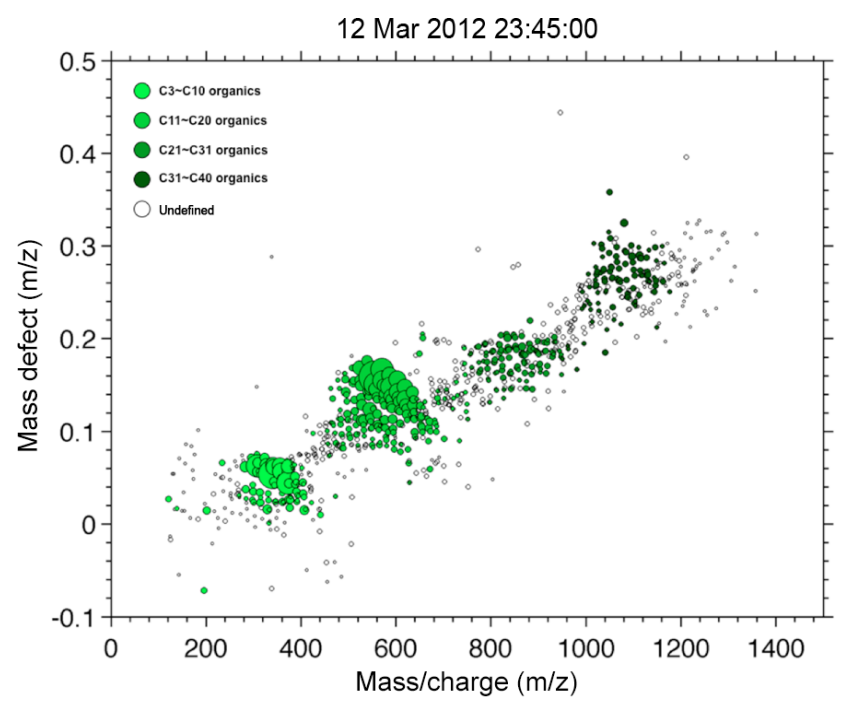

Figure 3. Mass defect plot of negative ambient ions observed during the night-time on 13 March 2012. The four bands represent the HOMs containing approximately 10, 20, 30 and 40 carbon atoms (four $\alpha$-pinene units). The majority of the HOMs have $\mathrm{NO}_{3}^{-}$as the core ion.

clusters (or oligomers). The first band is mainly composed of HOMs with roughly 9-10 carbon atoms and the second band with HOMs having 19-20 carbons. In general, the four bands show that these clusters can contain up to 40 carbon atoms. These larger molecules were previously detected during pure biogenic NPF in the CLOUD chamber from the ozonolysis of $\alpha$-pinene (Kirkby et al., 2016). This is also the first time that such compounds are recorded in the ambient atmosphere. Further studies will be designed to investigate the formation of such species and to identify their potential impact in NPF.

As mentioned previously, $\mathrm{HOM} \cdot \mathrm{NO}_{3}^{-}$and $\mathrm{HOM} \cdot \mathrm{HSO}_{4}^{-}$ adducts were identified using an APi-TOF. In Fig. 4, the most abundant HOMs and ONs detected during the day of 20 April 2013 (same as Fig. 2c) are presented. Ten HOMs (left panel) and nine ONs (right panel) were chosen for comparison. The bottom side of the bars refers to the HOMs/ONs clustered with $\mathrm{NO}_{3}^{-}$while the top part represents the fraction of signal intensity of the compounds with same chemical composition clustered with $\mathrm{HSO}_{4}^{-}$. We found that almost all $\mathrm{HOMs} / \mathrm{ONs}$ cluster more with $\mathrm{NO}_{3}^{-}$ions and on average $60 \%$ of the total signal $\left(\mathrm{HOMs} / \mathrm{ONs} \cdot \mathrm{NO}_{3}^{-}+\mathrm{HOMs} / \mathrm{ONs} \cdot \mathrm{HSO}_{4}^{-}\right.$) of these $19 \mathrm{com}-$ pounds are clustered with the nitrate. However, we should mention that we detected a $\mathrm{NO}_{3}^{-}$signal of $0.065 \mathrm{cps}$ (counts per second) and $\mathrm{HSO}_{4}^{-}$signal of $0.034 \mathrm{cps}$. This means that $\mathrm{NO}_{3}^{-}$has a concentration that is almost a factor of 2 higher than the bisulfate ion. This could explain why we see more clusters with $\mathrm{NO}_{3}^{-}$than with $\mathrm{HSO}_{4}^{-}$. However, if we consider all pure nitric acid clusters $\left(\mathrm{NO}_{3}^{-}+\mathrm{HNO}_{3} \mathrm{NO}_{3}^{-}\right)$the signal is around $(0.065+0.192)=0.257 \mathrm{cps}$, while for all pure sulfuric acid clusters $\left(\mathrm{HSO}_{4}^{-}+\mathrm{H}_{2} \mathrm{SO}_{4} \mathrm{HSO}_{4}^{-}+\left(\mathrm{H}_{2} \mathrm{SO}_{4}\right)_{2} \mathrm{HSO}_{4}^{-}\right)$ 


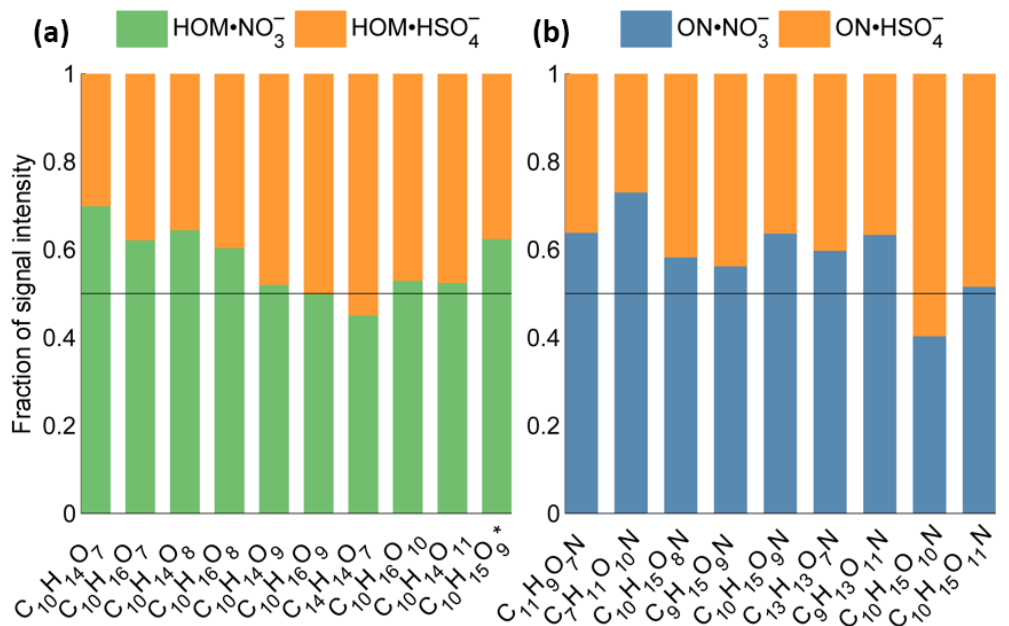

Figure 4. Naturally charged HOMs detected by the APi-TOF during daytime of 20 April 2013. In (a) we report the ambient ions that contain HOMs clustered ether with $\mathrm{NO}_{3}^{-}$(green) or $\mathrm{HSO}_{4}^{-}$(orange), while in (b) we show ambient ions that contain ONs clustered ether with $\mathrm{NO}_{3}^{-}$ (blue) or $\mathrm{HSO}_{4}^{-}$(orange).

the signal is around $(0.035+6.7+3.4)=10.135 \mathrm{cps}$. This means that sulfuric acid clusters have a concentration that is 40 times higher than that of the nitric acid clusters, showing once more that the sulfuric acid ions are the dominant peaks and that they cluster together very effectively.

\subsection{Diurnal variation of ions}

It is important to point out that different parameters could significantly impact the abundance of the ions detected in the atmosphere. For instance, the charging of the organic molecules is strongly affected by their concentration and their properties, such as proton affinity, which defines their ability to form clusters with nitrate or bisulfate ions. Indeed, a competition between the different compounds getting the charge will depend on their physical-chemical properties. For example, a strong electro-negative compound, sulfuric acid, produced during the day takes a large fraction of the negative charges available in the atmosphere. Such process will result in a reduction of other ambient ions, while the concentrations of the corresponding neutral species remain lower than the concentrations of other compounds. This phenomenon has to be taken into account while interpreting the diurnal variation of the ions, especially during daytime. A direct comparison of the neutral HOMs with the corresponding naturally charged HOMs helps to distinguish such processes since the CI-APi-TOF will measure the diurnal evolution of the compounds independently of the ion availability in the atmosphere.

Figure 5a shows the diurnal cycle of negative ions averaged over 28 days, most of them with sunny conditions, during spring 2013. In addition to that, for comparison, we added the time evolution of the neutral compounds in Fig. 5b. As expected, the diurnal evolution of sulfuric acid (neu- tral) and the pure sulfuric cluster-ions peak in the morning, since $\mathrm{H}_{2} \mathrm{SO}_{4}$, during the day, is mainly photochemically produced from the $\mathrm{OH}$ oxidation of $\mathrm{SO}_{2}$. Around 09:00 LT, three peaks attributed to sulfuric acid monomer $\left(\mathrm{HSO}_{4}^{-}\right)$, dimer $\left(\mathrm{H}_{2} \mathrm{SO}_{4} \mathrm{HSO}_{4}^{-}\right)$and trimer $\left(\mathrm{H}_{2} \mathrm{SO}_{4} \mathrm{H}_{2} \mathrm{SO}_{4} \mathrm{HSO}_{4}^{-}\right)$contribute to $\sim 20 \%$ of the total ion signal, which is comprised of several hundreds species. Therefore, during this time, there was less charge available for other compounds. In Fig. 6 we report a comparison of the sum of these three ion clusters with the measured neutral sulfuric acid concentration. As anticipated, as soon as sulfuric acid is produced, also these sulfuric acid-bisulfate ion clusters are formed, reaching their maximum around midday. However, from Fig. 5b, it is clear that sulfuric acid is far from being the most abundant neutral compound; among the negative ions in Fig. 5a, sulfuric acid clusters are the most intense family. Note that in Figs. 5a and 6 the signal has not been corrected by the transmission inside the APi-TOF that is usually around $0.1-2 \%$ depending on the mass range (Junninen et al., 2010).

The diurnal variation of these atmospheric ions is obviously influenced by the abundance of both various neutral molecules and the charge carriers, as well as the charging efficiency between them. The neutral HOMs are more abundant during the night-time, increasing at around 16:00 LT and decreasing at 04:00 LT, owing to the diurnal cycle of $\mathrm{NO}$, which during the day efficiently terminates the oxidation chain (Yan et al., 2016). During this period, nitrate is the dominant charge carrier due to the inefficient production of sulfuric acid. As a result, the $\mathrm{HOM} \cdot \mathrm{NO}_{3}^{-}$clusters reveal an almost identical diurnal pattern to the neutral HOMs. Corresponding with the decrease in neutral HOMs, the neutral ONs start to increase at around 04:00 LT in the morning, when the sulfuric concentration remains low and nitrate ions are still dominating, so a corresponding increase in the 

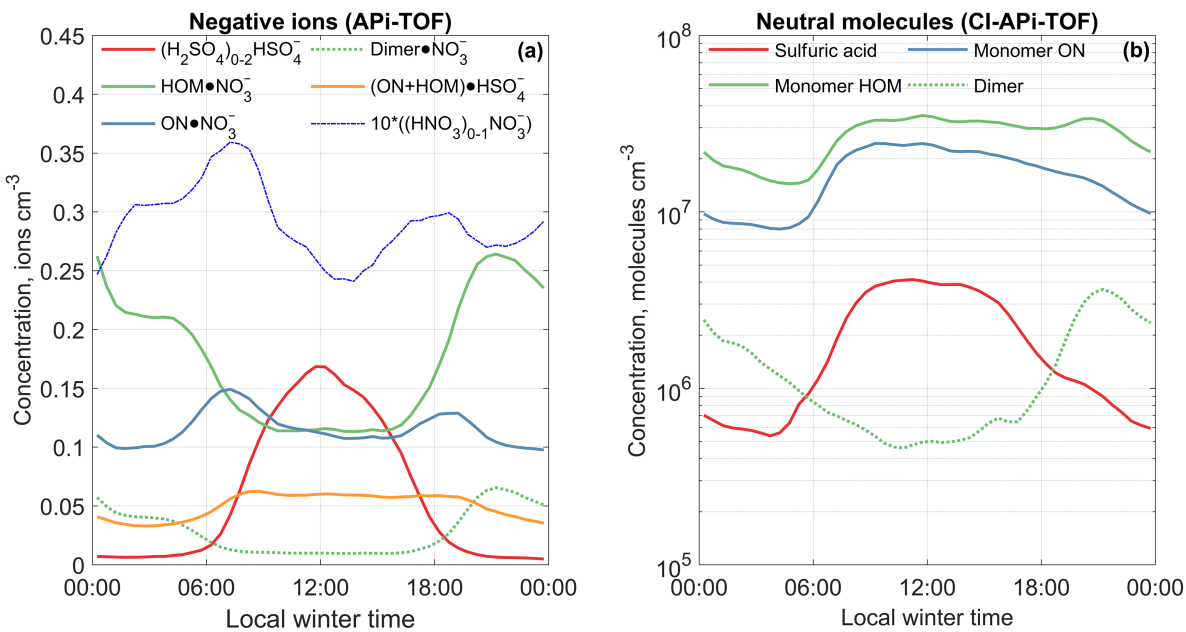

Figure 5. Averaged diurnal evolution of specific ion families (a) and neutral compounds (b) during days in clear sky conditions of measurements done in spring 2013. Colours and their corresponding families are denoted in the legends. Note that, in (a), the signal of the nitric acid clusters (blue dotted line) have been multiplied by 10 .

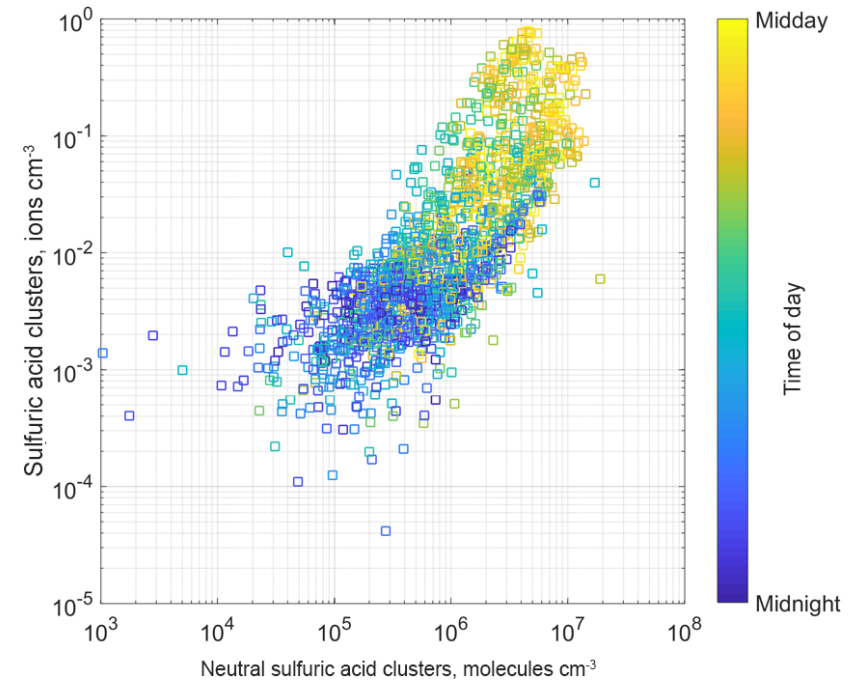

Figure 6. Correlation of negative sulfuric acid ion clusters $\left(\left(\mathrm{H}_{2} \mathrm{SO}_{4}\right)_{0-2} \mathrm{HSO}_{4}^{-}\right)$and the concentration of sulfuric acid, colour coded by the time of the day.

$\mathrm{ON} \cdot \mathrm{NO}_{3}^{-}$clusters is observed. These $\mathrm{ON} \cdot \mathrm{NO}_{3}^{-}$clusters reach their maximum at about 06:00 and started to decrease coincidentally with an increase in $\mathrm{ON}^{-} \mathrm{HSO}_{4}^{-}$clusters. We attribute this change to the shift of charge carrier from nitrate to bisulfate when the concentration of sulfuric acid is high enough to take most of the ions. When the concentration of sulfuric acid become even higher, it become more competitive in taking all ions, and more importantly, in clustering with $\mathrm{HSO}_{4}^{-}$. This leads to the reduction of $\mathrm{ON} \cdot \mathrm{HSO}_{4}^{-}$clusters and the increase in $\left(\mathrm{H}_{2} \mathrm{SO}_{4}\right)_{0-3} \mathrm{HSO}_{4}^{-}$clusters. Two important details should be noted here: (1) the concentration of neutral ONs also increase during the day and is usually more than 1 or-
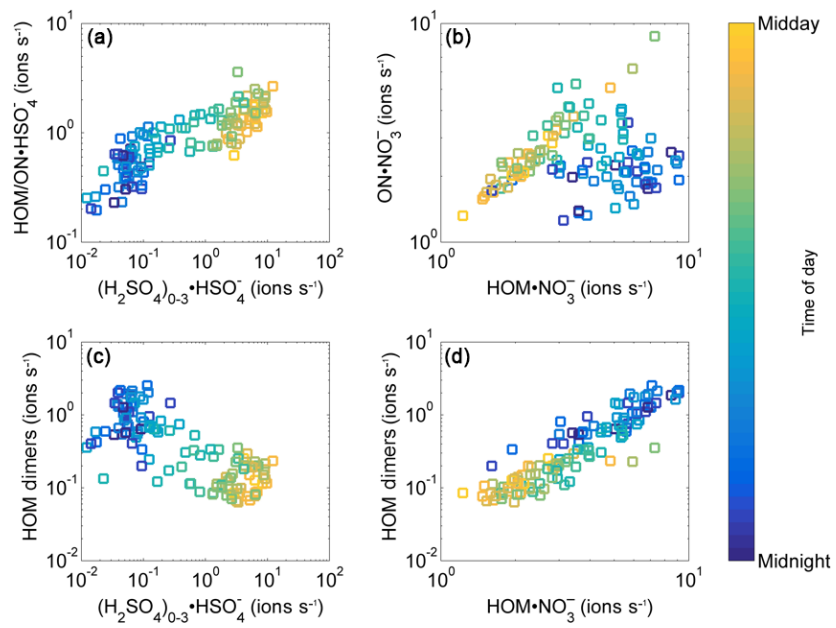

Figure 7. The diurnal dependency of ambient ions detected by the APi-TOF. The data points are hourly averages for 5 sunny days during April-May 2013. The colour scale is normalised to show the period between midnight and midday, so that the transition between blue to green is around 06:00 and 18:00 LT.

der of magnitude higher than that of sulfuric acid, so the shift from $\mathrm{ON} \cdot \mathrm{HSO}_{4}^{-}$to $\left(\mathrm{H}_{2} \mathrm{SO}_{4}\right)_{0-3} \mathrm{HSO}_{4}^{-}$clusters should be explained by the higher charging efficiency (or clustering probability) between sulfuric acid and $\mathrm{HSO}_{4}^{-}$; (2) such higher charging efficiency could be due to the appearance of the "stabiliser", such as $\mathrm{H}_{2} \mathrm{O}, \mathrm{NH}_{3}$ or amines (e.g. Kirkby et al., 2011; Almeida et al., 2013). The reverse change in ion composition from midday to midnight could have the same underlying causes. 
While Fig. 5 shows averaged values over 28 days, Fig. 7 shows the comparison of different ion families on hourly basis during 5 sunny days within the campaign period. Figure $7 \mathrm{a}$ shows the positive correlation between sulfuric acid clusters and organic molecules $(\mathrm{HOM}+\mathrm{ON})$ charged by bisulfate ion. This confirms our identification of $\mathrm{HOM} / \mathrm{ON} \cdot \mathrm{HSO}_{4}^{-}$compounds as both signals are connected to photochemical production of sulfuric acid during the day. Both of these ion families peak during the day and are absent during the night, which is consistent with Fig. 5a. On the other hand, sulfuric acid clusters anti-correlate with HOM dimers (Fig. 7c). As discussed before, the dimers contain two oxidised monoterpene units that are more abundant during the night as the termination reactions of $\mathrm{RO}_{2}$ radicals with NO, for example, are less likely. As the dimers are not produced efficiently during the day, they are primarily charged with $\mathrm{NO}_{3}^{-}$. Among the ionised species, dimers correlate with HOM monomers that are charged with nitrate (Fig. 7d); therefore, their diurnal profile will follow the green line in Fig. 5a. In Fig. 7d, we can observe two groups of points separated by night (blue) and day (green and yellow) as the processes that control the formation of HOM dimers and $\mathrm{HOM} \cdot \mathrm{NO}_{3}^{-}$are similar: during the day, it is the termination reaction of $\mathrm{RO}_{2}$ with $\mathrm{NO}$, while during the night it is the abundance of ozone and monoterpenes. Finally, in Fig. 7b, we can see that HOM and ON charged with nitrate show positive dependence during the day, while there is no correlation during the night. The night scatter results from the different formation pathways: oxidation of monoterpenes with $\mathrm{NO}_{3}$ radicals is responsible for $\mathrm{ON}$ production, while ozonolysis is responsible for HOM. During the day, the correlation between $\mathrm{ON} \cdot \mathrm{NO}_{3}^{-}$and $\mathrm{HOM} \cdot \mathrm{NO}_{3}^{-}$is coincidental and is driven by the shift in the charger availability from nitrate to bisulfate, as also seen in Fig. 5a.

\section{Conclusion}

Negative ambient ions from a Finnish boreal forest have been studied over a period of 2 months (March-April 2013). In order to determine the ion chemical composition, we used an APi-TOF. The results have also been compared with the chemical composition of the neutral compounds detected by the CI-APi-TOF. As expected, we found that during the day the most intense ions are composed of pure sulfuric acid clusters, but this correspond to only three ions out of the several hundred that were identified. We found that all the other peaks are mainly composed of HOMs or of ONs clustered with $\mathrm{NO}_{3}^{-}$ions. In addition to that, we also observed clusters potentially important for new particle formation composed of $\mathrm{HOMs} / \mathrm{ONs}$ and $\mathrm{HSO}_{4}^{-}$ions. During the night, sulfuric acid concentration is extremely low; as a result, the sulfuric acid clusters disappear. Therefore, the concentration of HOMs clustered with $\mathrm{HSO}_{4}^{-}$is also very low. As a result, during the night, almost all ions are formed by HOMs clus- tered with $\mathrm{NO}_{3}^{-}$. ONs are also less abundant at night because of the low NO concentration, although we still observe few $\mathrm{ON} \mathrm{NO}-$ adducts that arise from the $\mathrm{NO}_{3}$-initiated oxidation of monoterpene.

We have concluded that the chemical composition and diurnal variation of HOMs and ONs in neutral state as well as in negative ion adducts were almost identical and the differences are induced by the daytime abundance of sulfuric acid. This conclusion has been confirmed during all sunny days. Future studies will focus more on the clustering of the $\mathrm{HOMs} / \mathrm{ONs}$ with sulfuric acid and $\mathrm{HSO}_{4}^{-}$ions comparing days with and without NPF. Finally, it is important to note that for the first time we observed pure organic clusters that contain up to 40 carbon atoms (four $\alpha$-pinene units), confirming previous findings on pure organic ion-induced clustering.

Data availability. The time series of neutral compound groups, including sulfuric acid, as well as specific ion families and their calculated diurnal cycle are available at urn:nbn:fi:csckata20171115165621163630. For the raw and high-resolution mass spectrometer data as well as mass spectra, please contact the first author via email: federico.bianchi@helsinki.fi.

Competing interests. The authors declare that they have no conflict of interest.

Acknowledgements. Liine Heikkinen, Qiaozhi Zha and Clemence Rose are acknowledged for useful discussions. Alexey Adamov, Alessandro Franchin, Jonathan Duplissy, Maija Kajos, Putian Zhou, Simon Schallhart, Daniela Wimmer, Arnaud Praplan, Mikko Äijälä, Tuija Jokinen, Juha Kangasluoma, Katrianne Lehtipalo, Mikhail Paramonov, Ditte Taipale, EllaMaria Duplissy, Siegfried Schobesberger, and the personnel of the Hyytiälä forestry field station are acknowledged for help during field measurements. This work was partially funded by Swiss National Science Foundation (grant P2EZP2_168787), Academy of Finland (299574, Finnish Centre of Excellence 1141135), and European Research Council (COALA, grant 638703).

Edited by: Fangqun Yu

Reviewed by: two anonymous referees

\section{References}

Almeida, J., Schobesberger, S., Kuerten, A., Ortega, I. K., Kupiainen-Maatta, O., Praplan, A. P., Adamov, A., Amorim, A., Bianchi, F., Breitenlechner, M., David, A., Dommen, J., Donahue, N. M., Downard, A., Dunne, E., Duplissy, J., Ehrhart, S., Flagan, R. C., Franchin, A., Guida, R., Hakala, J., Hansel, A., Heinritzi, M., Henschel, H., Jokinen, T., Junninen, H., Kajos, M., Kangasluoma, J., Keskinen, H., Kupc, A., Kurten, T., Kvashin, A. N., Laaksonen, A., Lehtipalo, K., Leiminger, M., Leppa, J., Loukonen, V., Makhmutov, V., Mathot, S., McGrath, M. J., 
Nieminen, T., Olenius, T., Onnela, A., Petaja, T., Riccobono, F., Riipinen, I., Rissanen, M., Rondo, L., Ruuskanen, T., Santos, F. D., Sarnela, N., Schallhart, S., Schnitzhofer, R., Seinfeld, J. H., Simon, M., Sipila, M., Stozhkov, Y., Stratmann, F., Tome, A., Troestl, J., Tsagkogeorgas, G., Vaattovaara, P., Viisanen, Y., Virtanen, A., Vrtala, A., Wagner, P. E., Weingartner, E., Wex, H., Williamson, C., Wimmer, D., Ye, P., Yli-Juuti, T., Carslaw, K. S., Kulmala, M., Curtius, J., Baltensperger, U., Worsnop, D. R., Vehkamaki, H., and Kirkby, J.: Molecular understanding of sulphuric acid-amine particle nucleation in the atmosphere, Nature, 502, 359-363, https://doi.org/10.1038/nature12663, 2013.

Arnold, F.: Atmospheric ions and aerosol formation, Space Sci. Rev., 137, 225-239, 2008.

Berndt, T., Richters, S., Jokinen, T., Hyttinen, N., Kurten, T., Otkjaer, R. V., Kjaergaard, H. G., Stratmann, F., Herrmann, H., Sipila, M., Kulmala, M., and Ehn, M.: Hydroxyl radical-induced formation of highly oxidized organic compounds, Nat. Commun., 7, 8, https://doi.org/10.1038/ncomms13677, 2016.

Bianchi, F., Dommen, J., Mathot, S., and Baltensperger, U.: Online determination of ammonia at low pptv mixing ratios in the CLOUD chamber, Atmos. Meas. Tech., 5, 1719-1725, https://doi.org/10.5194/amt-5-1719-2012, 2012.

Bianchi, F., Praplan, A. P., Sarnela, N., Dommen, J., Kurten, A., Ortega, I. K., Schobesberger, S., Junninen, H., Simon, M., Trostl, J., Jokinen, T., Sipila, M., Adamov, A., Amorim, A., Almeida, J., Breitenlechner, M., Duplissy, J., Ehrhart, S., Flagan, R. C., Franchin, A., Hakala, J., Hansel, A., Heinritzi, M., Kangasluoma, J., Keskinen, H., Kim, J., Kirkby, J., Laaksonen, A., Lawler, M. J., Lehtipalo, K., Leiminger, M., Makhmutov, V., Mathot, S., Onnela, A., Petaja, T., Riccobono, F., Rissanen, M. P., Rondo, L., Tome, A., Virtanen, A., Viisanen, Y., Williamson, C., Wimmer, D., Winkler, P. M., Ye, P. L., Curtius, J., Kulmala, M., Worsnop, D. R., Donahue, N. M., and Baltensperger, U.: Insight into Acid-Base Nucleation Experiments by Comparison of the Chemical Composition of Positive, Negative, and Neutral Clusters, Environ. Sci. Technol., 48, 1367513684, https://doi.org/10.1021/es502380b, 2014.

Bianchi, F., Trostl, J., Junninen, H., Frege, C., Henne, S., Hoyle, C. R., Molteni, U., Herrmann, E., Adamov, A., Bukowiecki, N., Chen, X., Duplissy, J., Gysel, M., Hutterli, M., Kangasluoma, J., Kontkanen, J., Kurten, A., Manninen, H. E., Munch, S., Perakyla, O., Petaja, T., Rondo, L., Williamson, C., Weingartner, E., Curtius, J., Worsnop, D. R., Kulmala, M., Dommen, J., and Baltensperger, U.: New particle formation in the free troposphere: A question of chemistry and timing, Science, 352, 1109-1112, https://doi.org/10.1126/science.aad5456, 2016.

Crounse, J. D., Nielsen, L. B., Jorgensen, S., Kjaergaard, H. G., and Wennberg, P. O.: Autoxidation of Organic Compounds in the Atmosphere, J. Phys. Chem. Lett., 4, 3513-3520, https://doi.org/10.1021/jz4019207, 2013.

Duplissy, J., Merikanto, J., Franchin, A., Tsagkogeorgas, G., Kangasluoma, J., Wimmer, D., Vuollekoski, H., Schobesberger, S., Lehtipalo, K., Flagan, R. C., Brus, D., Donahue, N. M., Vehkamaki, H., Almeida, J., Amorim, A., Barmet, P., Bianchi, F., Breitenlechner, M., Dunne, E. M., Guida, R., Henschel, H., Junninen, H., Kirkby, J., Kurten, A., Kupc, A., Maattanen, A., Makhmutov, V., Mathot, S., Nieminen, T., Onnela, A., Praplan, A. P., Riccobono, F., Rondo, L., Steiner, G., Tome, A., Walther, H., Baltensperger, U., Carslaw, K. S., Dommen, J.,
Hansel, A., Petaja, T., Sipila, M., Stratmann, F., Vrtala, A., Wagner, P. E., Worsnop, D. R., Curtius, J., and Kulmala, M.: Effect of ions on sulfuric acid-water binary particle formation: 2. Experimental data and comparison with QC-normalized classical nucleation theory, J. Geophys. Res.-Atmos., 121, 1752-1775, https://doi.org/10.1002/2015jd023539, 2016.

Ehn, M., Junninen, H., Petäjä, T., Kurtén, T., Kerminen, V.-M., Schobesberger, S., Manninen, H. E., Ortega, I. K., Vehkamäki, H., Kulmala, M., and Worsnop, D. R.: Composition and temporal behaviour of ambient ions in the boreal forest, Atmos. Chem. Phys., 10, 8513-8530, https://doi.org/10.5194/acp-108513-2010, 2010.

Ehn, M., Kleist, E., Junninen, H., Petäjä, T., Lönn, G., Schobesberger, S., Dal Maso, M., Trimborn, A., Kulmala, M., Worsnop, D. R., Wahner, A., Wildt, J., and Mentel, Th. F.: Gas phase formation of extremely oxidized pinene reaction products in chamber and ambient air, Atmos. Chem. Phys., 12, 5113-5127, https://doi.org/10.5194/acp-12-5113-2012, 2012.

Ehn, M., Thornton, J. A., Kleist, E., Sipila, M., Junninen, H., Pullinen, I., Springer, M., Rubach, F., Tillmann, R., Lee, B., Lopez-Hilfiker, F., Andres, S., Acir, I. H., Rissanen, M., Jokinen, T., Schobesberger, S., Kangasluoma, J., Kontkanen, J., Nieminen, T., Kurten, T., Nielsen, L. B., Jorgensen, S., Kjaergaard, H. G., Canagaratna, M., Dal Maso, M., Berndt, T., Petaja, T., Wahner, A., Kerminen, V. M., Kulmala, M., Worsnop, D. R., Wildt, J., and Mentel, T. F.: A large source of lowvolatility secondary organic aerosol, Nature, 506, 476-480, https://doi.org/10.1038/nature13032, 2014.

Farmer, D. K., Matsunaga, A., Docherty, K. S., Surratt, J. D., Seinfeld, J. H., Ziemann, P. J., and Jimenez, J. L.: Response of an aerosol mass spectrometer to organonitrates and organosulfates and implications for atmospheric chemistry, P. Natl. Acad. Sci. USA, 107, 6670-6675, https://doi.org/10.1073/pnas.0912340107, 2010.

Hari, P. and Kulmala, M.: Station for measuring ecosystematmosphere relations (SMEAR II), Boreal Environ. Res., 10, 315-322, 2005.

Harrison, R. G. and Carslaw, K. S.: Ion-aerosol-cloud processes in the lower atmosphere, Rev. Geophys., 41, 26, https://doi.org/10.1029/2002rg000114, 2003.

Hirsikko, A., Nieminen, T., Gagné, S., Lehtipalo, K., Manninen, H. E., Ehn, M., Hõrrak, U., Kerminen, V.-M., Laakso, L., McMurry, P. H., Mirme, A., Mirme, S., Petäjä, T., Tammet, H., Vakkari, V., Vana, M., and Kulmala, M.: Atmospheric ions and nucleation: a review of observations, Atmos. Chem. Phys., 11, 767798, https://doi.org/10.5194/acp-11-767-2011, 2011.

Hyttinen, N., Kupiainen-Maatta, O., Rissanen, M. P., Muuronen, M., Ehn, M., and Kurten, T.: Modeling the Charging of Highly Oxidized Cyclohexene Ozonolysis Products Using Nitrate-Based Chemical Ionization, J. Phys. Chem. A, 119, 6339-6345, https://doi.org/10.1021/acs.jpca.5b01818, 2015.

Jokinen, T., Sipilä, M., Junninen, H., Ehn, M., Lönn, G., Hakala, J., Petäjä, T., Mauldin III, R. L., Kulmala, M., and Worsnop, D. R.: Atmospheric sulphuric acid and neutral cluster measurements using CI-APi-TOF, Atmos. Chem. Phys., 12, 4117-4125, https://doi.org/10.5194/acp-12-4117-2012, 2012.

Jokinen, T., Berndt, T., Makkonen, R., Kerminen, V. M., Junninen, H., Paasonen, P., Stratmann, F., Herrmann, H., Guenther, A. B., Worsnop, D. R., Kulmala, M., Ehn, M., and Sip- 
ila, M.: Production of extremely low volatile organic compounds from biogenic emissions: Measured yields and atmospheric implications, P. Natl. Acad. Sci. USA, 112, 7123-7128, https://doi.org/10.1073/pnas.1423977112, 2015.

Jokinen, T., Kontkanen, J., Lehtipalo, K., Manninen, H. E., Aalto, J., Porcar-Castell, A., Garmash, O., Nieminen, T., Ehn, M., Kangasluoma, J., Junninen, H., Levula, J., Duplissy, J., Ahonen, L. R., Rantala, P., Heikkinen, L., Yan, C., Sipilä, M., Worsnop, D. R., Bäck, J., Petäjä, T., Kerminen, V.-M., and Kulmala, M.: Solar eclipse demonstrating the importance of photochemistry in new particle formation, Sci. Rep., 7, 45707, https://doi.org/10.1038/srep45707, 2017.

Junninen, H., Ehn, M., Petäjä, T., Luosujärvi, L., Kotiaho, T., Kostiainen, R., Rohner, U., Gonin, M., Fuhrer, K., Kulmala, M., and Worsnop, D. R.: A high-resolution mass spectrometer to measure atmospheric ion composition, Atmos. Meas. Tech., 3, 10391053, https://doi.org/10.5194/amt-3-1039-2010, 2010.

Kiendler-Scharr, A., Mensah, A. A., Friese, E., Topping, D., Nemitz, E., Prevot, A. S. H., Aijala, M., Allan, J., Canonaco, F., Canagaratna, M., Carbone, S., Crippa, M., Dall Osto, M., Day, D. A., De Carlo, P., Di Marco, C. F., Elbern, H., Eriksson, A., Freney, E., Hao, L., Herrmann, H., Hildebrandt, L., Hillamo, R., Jimenez, J. L., Laaksonen, A., McFiggans, G., Mohr, C., O'Dowd, C., Otjes, R., Ovadnevaite, J., Pandis, S. N., Poulain, L., Schlag, P., Sellegri, K., Swietlicki, E., Tiitta, P., Vermeulen, A., Wahner, A., Worsnop, D., and Wu, H. C.: Ubiquity of organic nitrates from nighttime chemistry in the European submicron aerosol, Geophys. Res. Lett., 43, 7735-7744, https://doi.org/10.1002/2016g1069239, 2016.

Kirkby, J.: Cosmic rays and climate, Surv. Geophys., 28, 333-375, https://doi.org/10.1007/s10712-008-9030-6, 2007.

Kirkby, J., Curtius, J., Almeida, J., Dunne, E., Duplissy, J., Ehrhart, S., Franchin, A., Gagne, S., Ickes, L., Kurten, A., Kupc, A., Metzger, A., Riccobono, F., Rondo, L., Schobesberger, S., Tsagkogeorgas, G., Wimmer, D., Amorim, A., Bianchi, F., Breitenlechner, M., David, A., Dommen, J., Downard, A., Ehn, M., Flagan, R. C., Haider, S., Hansel, A., Hauser, D., Jud, W., Junninen, H., Kreissl, F., Kvashin, A., Laaksonen, A., Lehtipalo, K., Lima, J., Lovejoy, E. R., Makhmutov, V., Mathot, S., Mikkila, J., Minginette, P., Mogo, S., Nieminen, T., Onnela, A., Pereira, P., Petaja, T., Schnitzhofer, R., Seinfeld, J. H., Sipila, M., Stozhkov, Y., Stratmann, F., Tome, A., Vanhanen, J., Viisanen, Y., Vrtala, A., Wagner, P. E., Walther, H., Weingartner, E., Wex, H., Winkler, P. M., Carslaw, K. S., Worsnop, D. R., Baltensperger, U., and Kulmala, M.: Role of sulphuric acid, ammonia and galactic cosmic rays in atmospheric aerosol nucleation, Nature, 476, 429-433, https://doi.org/10.1038/nature10343, 2011.

Kirkby, J., Duplissy, J., Sengupta, K., Frege, C., Gordon, H., Williamson, C., Heinritzi, M., Simon, M., Yan, C., Almeida, J., Trostl, J., Nieminen, T., Ortega, I. K., Wagner, R., Adamov, A., Amorim, A., Bernhammer, A. K., Bianchi, F., Breitenlechner, M., Brilke, S., Chen, X. M., Craven, J., Dias, A., Ehrhart, S., Flagan, R. C., Franchin, A., Fuchs, C., Guida, R., Hakala, J., Hoyle, C. R., Jokinen, T., Junninen, H., Kangasluoma, J., Kim, J., Krapf, M., Kurten, A., Laaksonen, A., Lehtipalo, K., Makhmutov, V., Mathot, S., Molteni, U., Onnela, A., Perakyla, O., Piel, F., Petaja, T., Praplan, A. P., Pringle, K., Rap, A., Richards, N. A. D., Riipinen, I., Rissanen, M. P., Rondo, L., Sarnela, N., Schobesberger, S., Scott, C. E., Seinfeld, J. H., Sipila, M., Steiner, G., Stozhkov,
Y., Stratmann, F., Tome, A., Virtanen, A., Vogel, A. L., Wagner, A. C., Wagner, P. E., Weingartner, E., Wimmer, D., Winkler, P. M., Ye, P. L., Zhang, X., Hansel, A., Dommen, J., Donahue, N. M., Worsnop, D. R., Baltensperger, U., Kulmala, M., Carslaw, K. S., and Curtius, J.: Ion-induced nucleation of pure biogenic particles, Nature, 533, 521-425, https://doi.org/10.1038/nature17953, 2016.

Krechmer, J. E., Coggon, M. M., Massoli, P., Nguyen, T. B., Crounse, J. D., Hu, W. W., Day, D. A., Tyndall, G. S., Henze, D. K., Rivera-Rios, J. C., Nowak, J. B., Kimmel, J. R., Mauldin, R. L., Stark, H., Jayne, J. T., Sipila, M., Junninen, H., Clair, J. M. S., Zhang, X., Feiner, P. A., Zhang, L., Miller, D. O., Brune, W. H., Keutsch, F. N., Wennberg, P. O., Seinfeld, J. H., Worsnop, D. R., Jimenez, J. L., and Canagaratna, M. R.: Formation of Low Volatility Organic Compounds and Secondary Organic Aerosol from Isoprene Hydroxyhydroperoxide Low-NO Oxidation, Environ. Sci. Technol., 49, 10330-10339, https://doi.org/10.1021/acs.est.5b02031, 2015.

Kulmala, M., Toivonen, A., Mäkelä, J. M., and Laaksonen, A.: Analysis of the growth of nucleation mode particles observed in Boreal forest, Tellus B, 50, 449-462, 1998.

Kulmala, M., Kontkanen, J., Junninen, H., Lehtipalo, K., Manninen, H. E., Nieminen, T., Petäjä, T., Sipilä, M., Schobesberger, S., Rantala, P., Franchin, A., Jokinen, T., Järvinen, E., Äijälä, M., Kangasluoma, J., Hakala, J., Aalto, P. P., Paasonen, P., Mikkilä, J., Vanhanen, J., Aalto, J., Hakola, H., Makkonen, U., Ruuskanen, T., Mauldin, R. L., Duplissy, J., Vehkamäki, H., Bäck, J., Kortelainen, A., Riipinen, I., Kurtén, T., Johnston, M. V., Smith, J. N., Ehn, M., Mentel, T. F., Lehtinen, K. E. J., Laaksonen, A., Kerminen, V.-M., and Worsnop, D. R.: Direct Observations of Atmospheric Aerosol Nucleation, Science, 339, 943-946, 2013.

Kürten, A., Rondo, L., Ehrhart, S., and Curtius, J.: Performance of a corona ion source for measurement of sulfuric acid by chemical ionization mass spectrometry, Atmos. Meas. Tech., 4, 437-443, https://doi.org/10.5194/amt-4-437-2011, 2011.

Kürten, A., Jokinen, T., Simon, M., Sipila, M., Sarnela, N., Junninen, H., Adamov, A., Almeida, J., Amorim, A., Bianchi, F., Breitenlechner, M., Dommen, J., Donahue, N. M., Duplissy, J., Ehrhart, S., Flagan, R. C., Franchin, A., Hakala, J., Hansel, A., Heinritzi, M., Hutterli, M., Kangasluoma, J., Kirkby, J., Laaksonen, A., Lehtipalo, K., Leiminger, M., Makhmutov, V., Mathot, S., Onnela, A., Petaja, T., Praplan, A. P., Riccobono, F., Rissanen, M. P., Rondo, L., Schobesberger, S., Seinfeld, J. H., Steiner, G., Tome, A., Troestl, J., Winkler, P. M., Williamson, C., Wimmer, D., Ye, P., Baltensperger, U., Carslaw, K. S., Kulmala, M., Worsnop, D. R., and Curtius, J.: Neutral molecular cluster formation of sulfuric acid-dimethylamine observed in real time under atmospheric conditions, P. Natl. Acad. Sci. USA, 111, 1501915024, https://doi.org/10.1073/pnas.1404853111, 2014.

Kürten, A., Bianchi, F., Almeida, J., Kupiainen-Maatta, O., Dunne, E. M., Duplissy, J., Williamson, C., Barmet, P., Breitenlechner, M., Dommen, J., Donahue, N. M., Flagan, R. C., Franchin, A., Gordon, H., Hakala, J., Hansel, A., Heinritzi, M., Ickes, L., Jokinen, T., Kangasluoma, J., Kim, J., Kirkby, J., Kupc, A., Lehtipalo, K., Leiminger, M., Makhmutov, V., Onnela, A., Ortega, I. K., Petaja, T., Praplan, A. P., Riccobono, F., Rissanen, M. P., Rondo, L., Schnitzhofer, R., Schobesberger, S., Smith, J. N., Steiner, G., Stozhkov, Y., Tome, A., Trostl, J., Tsagkogeorgas, G., Wagner, P. E., Wimmer, D., Ye, P. L., 
Baltensperger, U., Carslaw, K., Kulmala, M., and Curtius, J.: Experimental particle formation rates spanning tropospheric sulfuric acid and ammonia abundances, ion production rates, and temperatures, J. Geophys. Res.-Atmos., 121, 12377-12400, https://doi.org/10.1002/2015jd023908, 2016.

Laakso, L., Anttila, T., Lehtinen, K. E. J., Aalto, P. P., Kulmala, M., Hõrrak, U., Paatero, J., Hanke, M., and Arnold, F.: Kinetic nucleation and ions in boreal forest particle formation events, Atmos. Chem. Phys., 4, 2353-2366, https://doi.org/10.5194/acp-4-23532004, 2004.

Lee, B. H., Mohr, C., Lopez-Hilfiker, F. D., Lutz, A., Hallquist, M., Lee, L., Romer, P., Cohen, R. C., Iyer, S., Kurten, T., Hu, W. W., Day, D. A., Campuzano-Jost, P., Jimenez, J. L., Xu, L., Ng, N. L., Guo, H. Y., Weber, R. J., Wild, R. J., Brown, S. S., Koss, A., de Gouw, J., Olson, K., Goldstein, A. H., Seco, R., Kim, S., McAvey, K., Shepson, P. B., Starn, T., Baumann, K., Edgerton, E. S., Liu, J. M., Shilling, J. E., Miller, D. O., Brune, W., Schobesberger, S., D'Ambro, E. L., and Thornton, J. A.: Highly functionalized organic nitrates in the southeast United States: Contribution to secondary organic aerosol and reactive nitrogen budgets, P. Natl. Acad. Sci. USA, 113, 1516-1521, https://doi.org/10.1073/pnas.1508108113, 2016.

Lopez-Hilfiker, F. D., Mohr, C., Ehn, M., Rubach, F., Kleist, E., Wildt, J., Mentel, T. F., Lutz, A., Hallquist, M., Worsnop, D., and Thornton, J. A.: A novel method for online analysis of gas and particle composition: description and evaluation of a Filter Inlet for Gases and AEROsols (FIGAERO), Atmos. Meas. Tech., 7, 983-1001, https://doi.org/10.5194/amt-7-983-2014, 2014.

Ng, N. L., Brown, S. S., Archibald, A. T., Atlas, E., Cohen, R. C., Crowley, J. N., Day, D. A., Donahue, N. M., Fry, J. L., Fuchs, H., Griffin, R. J., Guzman, M. I., Herrmann, H., Hodzic, A., Iinuma, Y., Jimenez, J. L., Kiendler-Scharr, A., Lee, B. H., Luecken, D. J., Mao, J., McLaren, R., Mutzel, A., Osthoff, H. D., Ouyang, B., Picquet-Varrault, B., Platt, U., Pye, H. O. T., Rudich, Y., Schwantes, R. H., Shiraiwa, M., Stutz, J., Thornton, J. A., Tilgner, A., Williams, B. J., and Zaveri, R. A.: Nitrate radicals and biogenic volatile organic compounds: oxidation, mechanisms, and organic aerosol, Atmos. Chem. Phys., 17, 2103-2162, https://doi.org/10.5194/acp-17-2103-2017, 2017.

Ortega, A. M., Hayes, P. L., Peng, Z., Palm, B. B., Hu, W. W., Day, D. A., Li, R., Cubison, M. J., Brune, W. H., Graus, M., Warneke, C., Gilman, J. B., Kuster, W. C., de Gouw, J., GutierrezMontes, C., and Jimenez, J. L.: Real-time measurements of secondary organic aerosol formation and aging from ambient air in an oxidation flow reactor in the Los Angeles area, Atmos. Chem. Phys., 16, 7411-7433, https://doi.org/10.5194/acp16-7411-2016, 2016.

Raes, F., Janssens, A., and Vandingenen, R.: The role of ion-induced aerosol formation in the lower atmosphere, J. Aerosol Sci., 17, 466-470, https://doi.org/10.1016/0021-8502(86)90135-7, 1986.

Riccobono, F., Schobesberger, S., Scott, C. E., Dommen, J., Ortega, I. K., Rondo, L., Almeida, J., Amorim, A., Bianchi, F., Breitenlechner, M., David, A., Downard, A., Dunne, E. M., Duplissy, J., Ehrhart, S., Flagan, R. C., Franchin, A., Hansel, A., Junninen, H., Kajos, M., Keskinen, H., Kupc, A., Kurten, A., Kvashin, A. N., Laaksonen, A., Lehtipalo, K., Makhmutov, V., Mathot, S., Nieminen, T., Onnela, A., Petaja, T., Praplan, A. P., Santos, F. D., Schallhart, S., Seinfeld, J. H., Sipila, M., Spracklen, D. V., Stozhkov, Y., Stratmann, F., Tome, A., Tsagkogeorgas, G.,
Vaattovaara, P., Viisanen, Y., Vrtala, A., Wagner, P. E., Weingartner, E., Wex, H., Wimmer, D., Carslaw, K. S., Curtius, J., Donahue, N. M., Kirkby, J., Kulmala, M., Worsnop, D. R., and Baltensperger, U.: Oxidation Products of Biogenic Emissions Contribute to Nucleation of Atmospheric Particles, Science, 344, 717-721, https://doi.org/10.1126/science.1243527, 2014.

Rissanen, M. P., Kurten, T., Sipila, M., Thornton, J. A., Kangasluoma, J., Sarnela, N., Junninen, H., Jorgensen, S., Schallhart, S., Kajos, M. K., Taipale, R., Springer, M., Mentel, T. F., Ruuskanen, T., Petaja, T., Worsnop, D. R., Kjaergaard, H. G., and Ehn, M.: The Formation of Highly Oxidized Multifunctional Products in the Ozonolysis of Cyclohexene, J. Am. Chem. Soc., 136, 15596-15606, https://doi.org/10.1021/ja507146s, 2014.

Schobesberger, S., Junninen, H., Bianchi, F., Lonn, G., Ehn, M., Lehtipalo, K., Dommen, J., Ehrhart, S., Ortega, I. K., Franchin, A., Nieminen, T., Riccobono, F., Hutterli, M., Duplissy, J., Almeida, J., Amorim, A., Breitenlechner, M., Downard, A. J., Dunne, E. M., Flagan, R. C., Kajos, M., Keskinen, H., Kirkby, J., Kupc, A., Kuerten, A., Kurten, T., Laaksonen, A., Mathot, S., Onnela, A., Praplan, A. P., Rondo, L., Santos, F. D., Schallhart, S., Schnitzhofer, R., Sipila, M., Tome, A., Tsagkogeorgas, G., Vehkamaki, H., Wimmer, D., Baltensperger, U., Carslaw, K. S., Curtius, J., Hansel, A., Petaja, T., Kulmala, M., Donahue, N. M., and Worsnop, D. R.: Molecular understanding of atmospheric particle formation from sulfuric acid and large oxidized organic molecules, P. Natl. Acad. Sci. USA, 110, 17223-17228, https://doi.org/10.1073/pnas.1306973110, 2013.

Schobesberger, S., Franchin, A., Bianchi, F., Rondo, L., Duplissy, J., Kürten, A., Ortega, I. K., Metzger, A., Schnitzhofer, R., Almeida, J., Amorim, A., Dommen, J., Dunne, E. M., Ehn, M., Gagné, S., Ickes, L., Junninen, H., Hansel, A., Kerminen, V.-M., Kirkby, J., Kupc, A., Laaksonen, A., Lehtipalo, K., Mathot, S., Onnela, A., Petäjä, T., Riccobono, F., Santos, F. D., Sipilä, M., Tomé, A., Tsagkogeorgas, G., Viisanen, Y., Wagner, P. E., Wimmer, D., Curtius, J., Donahue, N. M., Baltensperger, U., Kulmala, M., and Worsnop, D. R.: On the composition of ammonia-sulfuric-acid ion clusters during aerosol particle formation, Atmos. Chem. Phys., 15, 55-78, https://doi.org/10.5194/acp-15-55-2015, 2015.

Smith, D. and Spanel, P.: Ions in the terrestrial atmosphere and in interstellar clouds, Mass Spectrom. Rev., 14, 255-278, https://doi.org/10.1002/mas.1280140403, 1995.

Tröstl, J., Chuang, W. K., Gordon, H., Heinritzi, M., Yan, C., Molteni, U., Ahlm, L., Frege, C., Bianchi, F., Wagner, R., Simon, M., Lehtipalo, K., Williamson, C., Craven, J. S., Duplissy, J., Adamov, A., Almeida, J., Bernhammer, A. K., Breitenlechner, M., Brilke, S., Dias, A., Ehrhart, S., Flagan, R. C., Franchin, A., Fuchs, C., Guida, R., Gysel, M., Hansel, A., Hoyle, C. R., Jokinen, T., Junninen, H., Kangasluoma, J., Keskinen, H., Kim, J., Krapf, M., Kurten, A., Laaksonen, A., Lawler, M., Leiminger, M., Mathot, S., Mohler, O., Nieminen, T., Onnela, A., Petaja, T., Piel, F. M., Miettinen, P., Rissanen, M. P., Rondo, L., Sarnela, N., Schobesberger, S., Sengupta, K., Sipila, M., Smith, J. N., Steiner, G., Tome, A., Virtanen, A., Wagner, A. C., Weingartner, E., Wimmer, D., Winkler, P. M., Ye, P. L., Carslaw, K. S., Curtius, J., Dommen, J., Kirkby, J., Kulmala, M., Riipinen, I., Worsnop, D. R., Donahue, N. M., and Baltensperger, U.: The role of low-volatility organic compounds in initial particle growth in the atmosphere, Nature, 533, 527-531, https://doi.org/10.1038/nature18271, 2016. 
Yan, C., Nie, W., Äijälä, M., Rissanen, M. P., Canagaratna, M. R., Massoli, P., Junninen, H., Jokinen, T., Sarnela, N., Häme, S. A. K., Schobesberger, S., Canonaco, F., Yao, L., Prévôt, A. S. H., Petäjä, T., Kulmala, M., Sipilä, M., Worsnop, D. R., and Ehn, M.: Source characterization of highly oxidized multifunctional compounds in a boreal forest environment using positive matrix factorization, Atmos. Chem. Phys., 16, 12715-12731, https://doi.org/10.5194/acp-16-12715-2016, 2016.
Yu, F. and Turco, R. P.: From molecular clusters to nanoparticles: Role of ambient ionization in tropospheric aerosol formation, J. Geophys. Res.-Atmos., 106, 4797-4814, 2001. 